\title{
Time Varying International Market Integration
}

\author{
Dhouha Hadidane Chkioua ${ }^{1}$ \\ ${ }^{1}$ ESSEC Tunis, University of Tunis, Tunisia \\ Correspondence: Dhouha Hadidane Chkioua, ESSEC Tunis, University of Tunis, 4 Rue Abou Zakaria El Hafsi, \\ 1089 Montfleury, Tunisia. Tel: 216-99-344-699. E-mail: dhouhachk@yahoo.fr
}

$\begin{array}{ll}\text { Received: February 11, } 2013 & \text { Accepted: October 9, } 2013 \quad \text { Online Published: October 26, } 2013 \\ \text { doi:10.5539/ijef.v5n11p63 } & \text { URL: http://dx.doi.org/10.5539/ijef.v5n11p63 }\end{array}$

\begin{abstract}
The objective of this paper is to test financial integration for a sample of 15 developed financial markets and 7 emerging markets between December 1987 and December 2004 by using Conditional International CAPM. The results of the test of International CAPM with time-varying moments provide evidence that the world portfolio is conditionally mean-variance efficient for the group of G7 countries. For emerging markets, we reject the hypothesis of integrated capital markets and we find evidence of time-varying segmentation.
\end{abstract}

Keywords: international CAPM, financial integration, GMM

\section{Introduction and Literature Review}

The portfolio modern theory showed that the most gains of international diversification come from segmentation of financial markets. Stulz (1981) defines segmentation as a situation where two assets with the same risk in different national markets have different expected returns. In absence of the barriers to international investment, an investor should choose the asset having more return and thus profits of an arbitrage situation.

The markets are integrated if securities with the same risk have identical expected returns in different countries. The risk is related to the exposure to a world common factor. If a market is segmented internationally, its covariance with this world factor does not explain its expected return (Bekaert \& Harvey, 1995). Yu, Fung and tam (2010) showed that financial integration is important to stabilize financial markets and to reduce economic shocks. Esqueda, Assefa and Mollick (2012) found that financial integration reduces total stock return volatility for emerging markets over 1995-2007.

Several financial integration tests were proposed, we can quote the tests based on standard CAPM and international CAPM, the tests using consumption CAPM, the studies examining the degree of market segmentation, etc.

The financial integration tests based on CAPM, seek to determine empirically that international CAPM provides a better model of capital asset pricing than domestic CAPM. Solnik (1974) compared the international and domestic versions of the CAPM for a sample of 234 stocks listed on the 9 larger markets in the world during 1966-1971, the results show that domestic factors are more influential than international factor. Jorion and Schwartz (1986) showed that international CAPM International does not constitute the suitable model for Canadian asset pricing during the period 1963-1982. Tai (2007) examined the impact of Asian stock market liberalization on their integration into the world capital market in the absence of purchasing power parity (Note 1). By testing a dynamic version of the model of Errunza and Losq (1985) which stipulates that expected returns depend on the risk of domestic market and the risk of worldwide market and by introducing the exchange rate risk (Note 2), Tai (2007) showed that these risk factors are important in the explanation of the return dynamics in emerging markets. Hunter (2007) used ADRs to examine if emerging markets of Argentina, Chile and Mexico became more integrated during the post-liberalization. The empirical results indicate that these markets did not become integrated after their liberalization because of the impact of currency crises on market segmentation.

Other financial integration tests use the consumption based CAPM. Wheatley (1988) proposed a model with taxes on foreign assets and showed that the real returns of American and foreign portfolios are linear function of their beta consumption. The results state that the non American portfolios do not move away the domestic security market line, which indicates that international capital markets are internationally integrated.

A number of studies seek to determine the degree of market integration with the rest of the world. Akdogan 
(1996) used a fundamental instrument of modern portfolio theory, namely the decomposition of the risk in order to determine the degree by which a market is segmented from the rest of the world. The results indicate that some markets become more integrated in decade 80, such as the United Kingdom, Japan, France and Australia and that other European markets, such as Finland, Spain, Denmark and Italy display a slightly segmented structure. By studying the time varying integration scores of Latin America markets (Note 3), Barari (2004) showed that these countries were regionally integrated until the mid of the 1990's and from the second half of the 1990 's , they became globally integrated.

Boubakri and Guillaumin (2011) studied the dynamics of financial integration in the euro zone. The results show that financial integration is rising and is related to currency volatility. Arouri and Foulquier (2012) showed that the financial integration is time-varying and the local risk is the most important component of the global risk. The results indicated that most of the emerging markets become more integrated as a result of liberalization.

The purpose of this paper is to check the capacity of the conditional International Capital Asset Pricing Model to capture the dynamic behavior of stock returns in 22 countries and to test the mean-variance efficiency of the worldwide portfolio. The paper is structured as follows. We initially present the measures of the conditional moments of stock returns. We then calculate the time-varying covariances for each country and for the group of G7 countries in order to explain the dynamic behavior of the stock returns and we analyze the results. We finally present some concluding remarks.

\section{The Conditional International CAPM}

The conditional version of CAPM, supposes that the conditionally expected stock return depends on the market portfolio. The model is as follows:

$$
E\left[r_{j t} \mid \Omega_{t-1}\right]=\frac{E\left[r_{m t} \mid \Omega_{t-1}\right]}{\operatorname{Var}\left[r_{m t} \mid \Omega_{t-1}\right]} \operatorname{Cov}\left[r_{j t}, r_{m t} \mid \Omega_{t-1}\right]
$$

Where;

$r_{j t}$ : The return on country portfolio in excess of risk free;

$r_{m i}:$ The return on world portfolio in excess of risk free;

$\Omega_{t-1}$ : Information used to predict the prices of securities;

$E\left[r_{m t} \mid \Omega_{t-1}\right]:$ The expected return on the worldwide market;

$\operatorname{Var}\left[r_{m t} \mid \Omega_{t-1}\right]$ : The variance of the worldwide market;

$\frac{E\left[r_{m t} \mid \Omega_{t-1}\right]}{\operatorname{Var}\left[r_{m t} \mid \Omega_{t-1}\right]}$ : The international reward to risk covariance.

To test the equation (1), we will follow the methodology of Harvey (1991). For that, we will suppose that the investors reach only a subset of information $Z_{t-1}$, the estimated disturbance is the difference between the realized return and the expected return:

$$
u_{j t}=r_{j t}-Z_{t-1} \delta_{j}
$$

Where;

$u_{j t}$ : The estimated error for the return on the market $\mathrm{j}$;

$Z_{\mathrm{t}-1}: l$ Information variables accessible;

$\delta_{j}$ : Coefficients used to predict the expected returns.

The equation (1) can then be expressed as follows (Note 4):

Where;

$$
Z_{t-1} \delta_{j}=\frac{Z_{t-1} \delta_{m}}{E\left[u_{m t}^{2} \mid Z_{t-1}\right]} E\left[u_{j t} u_{m t} \mid Z_{t-1}\right]
$$

$u_{m}$ : The estimated disturbance for the return on worldwide market. 
If we multiply by the conditional variance, we obtain (Note 5):

$$
\left.E\left|u_{m t}^{2} Z_{t-1} \delta_{j}\right| Z_{t-1}\right]=E\left[u_{j t} u_{m t} Z_{t-1} \delta_{m} \mid Z_{t-1}\right]
$$

The difference from the anticipation is:

$$
h_{j t}=u_{m t}^{2} Z_{t-1} \delta_{j}-u_{j t} u_{m t} Z_{t-1} \delta_{m}
$$

Where;

$h_{j t}$ : The error under the restriction that the Conditional CAPM is valid.

Using the equations (2) and (5), the model to test is the following:

$$
\varepsilon_{t}=\left(u_{t} u_{m t} h_{t}\right)=\left(\begin{array}{c}
{\left[r_{t}-Z_{t-1} \delta\right]^{\prime}} \\
{\left[r_{m t}-Z_{t-1} \delta_{m}\right]^{\prime}} \\
{\left[u_{m t}^{2} Z_{t-1} \delta-u_{m t} u_{t} Z_{t-1} \delta_{m}\right]}
\end{array}\right)
$$

Where;

$u$ : A $(1 \times \mathrm{n})$ vector of disturbances in the stock market average returns, $\mathrm{n}$ is the number of countries.

\section{Data Description}

The study is conducted from the prospect for an American investor. The returns are thus calculated in American dollar. All the returns are calculated in excess of the one month American Treasury bill. The data used in this study are the world index, the global index of emerging markets and the equity indices of 15 developed markets and 7 emerging markets (Note 6). The data are of monthly periodicity and extracted from Morgan Stanley Capital International from December 1987 to December 2004.

Since the stock returns are supposed to be time-varying in our study, it is necessary to introduce instrumental variables in order to predict the returns. In accordance with Harvey (1991) and Bekaert and Harvey (1995), we use two sets of instrumental variables: global instruments for all the countries and local instruments specific to countries. The global instruments are composed of the lagged world excess stock return, an indicator variable for January, the change of the US term structure of interest rates, the US bond yield spread (Note 7). The local instrumental variables are the lagged stock market returns.

\section{Descriptive Statistics}

We calculated the averages and the standard deviations for developed and emerging markets during the period 1987-2004, the results indicate that the mean excess returns for developed countries range between $-0.02 \%$ (Japan) and 1.1\% (Sweden), while the average returns for emerging countries are between $0.67 \%$ (Malaysia) and 2.3\% (Argentina). Indeed, except for Korea, Malaysia and Thailand, emerging markets have the highest returns. Moreover, these markets are much more volatile than mature markets. Therefore, emerging markets are characterized by a couple risk-return high in the sense of Markowitz.

We also notice that the United States has the smallest volatility and dominates the other countries in terms of risk minimization. The risk level of US market is similar to that of the world market portfolio. For a risk adverse investor, investing in the world portfolio or in the US market delivers the lowest standard deviation. This result is not surprising, since the US market occupies a significant part of the world portfolio, which is expressed in the correlation between US market and the world market (0.83).

The calculation of unconditional correlations shows that it is interesting to invest in emerging countries and to reduce the total risk of portfolios because of their low correlation levels. The correlations of the equity returns between emerging markets and developed markets are very weak and sometimes negative for countries such as Argentina. The correlation between developed markets and the world index varies between 0.37 (Austria) and 0.83 (the United States), while it varies between 0.13 (Argentina) and 0.45 (Mexico) for emerging markets.

The study of simple autocorrelation functions indicates that except for Australia and Austria, the first-order autocorrelations of developed market returns are not significant. The emerging market returns are more autocorrelated than developed markets. Argentina, Chile, Malaysia as well as the global index of emerging markets exhibit high autocorrelations.

\section{Empirical Results}

To estimate the parameters of the equation (6), we will use the Generalized Moment Method (GMM) of Hansen 
(1982). The tests were carried out for each country and the group of G7 countries. The overidentifying statistics or J-statistics, present a freedom degree equal to the difference between the number of moment conditions and the number of parameters estimated. These statistics examine the restriction that the worldwide portfolio is efficient (Note 8). The $R^{2}$ statistics represent the adjusted determination coefficient from a regression of the model disturbances on the global instrumental variables. If the model is correctly specified, the disturbances would not be related to instruments (Note 9).

The Conditional International CAPM for individual countries, tests the hypothesis that the country expected return depends on the covariance with the international market. For the group of G7 countries, the model tests the hypothesis that the international risk reward is constant in the 7 larger countries of the world.

The estimation results for single countries with common instruments indicate that the hypotheses of the model are not validated for 7 developed countries: Australia, Belgium, Canada, Hong Kong, Japan, the Netherlands and Switzerland. With the local instruments, the hypotheses are checked for Canada and Switzerland.

For emerging markets, the single country estimation results depend on the choice of the information set. Using common variables, the CAPM's hypothesis are validated only for two countries: Argentina and Malaysia. With local instruments, the null hypotheses of world market efficiency became valid for 4 countries (Argentina, Korea, Malaysia and Indonesia). For the group of G7 countries, the world portfolio is efficient with local or common information variables.

The tables provide the pricing errors based on estimates with common instrumental variables. Positive errors are noted for Austria, Italy and the Netherlands, (for developed countries), Korea, Indonesia, Mexico and Thailand (for emerging markets), which indicate that given the risk level, the observed return is upper than the anticipated return. In the same way, it is important to announce that the United States record the weakest pricing error during 1987-2004. We also notice that the classification of conditional covariances is different from that of the returns. However, it is interesting to show that Sweden presents the highest conditional covariance and the highest return.

Table 1. Estimates of the conditional CAPM for emerging markets (Note 10)

\begin{tabular}{|c|c|c|c|c|c|c|}
\hline $\begin{array}{l}\text { Emerging } \\
\text { Markets }\end{array}$ & & $\begin{array}{l}\text { Conditional } \\
\text { Covariance }\end{array}$ & Pricing Error & $\overline{R^{2}}$ & $\begin{array}{l}\text { J Statistic with } \\
\text { common } \\
\text { instruments } \\
\text { (P-value) }\end{array}$ & $\begin{array}{c}\text { J Statistic with } \\
\text { local } \\
\text { instruments } \\
\text { (P-value) }\end{array}$ \\
\hline Argentina & 0.0231 & 1.100 & -0.01331 & -0.0128 & $\begin{array}{c}0.03658 \\
(0.114)\end{array}$ & $\begin{array}{c}0.0340 \\
(0.1409)\end{array}$ \\
\hline Chile & 0.0125 & 1.048 & -0.00523 & -0.0085 & $\begin{array}{c}0.058048 \\
(0.0190)\end{array}$ & $\begin{array}{c}0.0556 \\
(0.0234)\end{array}$ \\
\hline Indonesia & 0.0141 & 1.515 & 0.014793 & 0.0109 & $\begin{array}{c}0.059194 \\
(0.0172)\end{array}$ & $\begin{array}{c}0.0408 \\
(0.0811)\end{array}$ \\
\hline Korea & 0.0083 & 2.099 & 0.010102 & 0.0176 & $\begin{array}{c}0.047972 \\
(0.0450)\end{array}$ & $\begin{array}{c}0.0333 \\
(0.1483)\end{array}$ \\
\hline Malaysia & 0.0067 & 1.541 & -0.04367 & -0.0121 & $\begin{array}{c}0.042613 \\
(0.070)\end{array}$ & $\begin{array}{c}0.0416 \\
(0.0760)\end{array}$ \\
\hline Mexico & 0.0196 & 1.845 & 0.014193 & -0.0134 & $\begin{array}{c}0.060943 \\
(0.0147)\end{array}$ & $\begin{array}{c}0.0517 \\
(0.0326)\end{array}$ \\
\hline Thailand & 0.0083 & 2.122 & 0.004275 & 0.01126 & $\begin{array}{c}0.048467 \\
(0.0432)\end{array}$ & $\begin{array}{c}0.0546 \\
(0.0254)\end{array}$ \\
\hline
\end{tabular}


Table 2. Estimates of the conditional CAPM for developed markets

\begin{tabular}{|c|c|c|c|c|c|c|}
\hline $\begin{array}{l}\text { Developed } \\
\text { Markets }\end{array}$ & $\begin{array}{l}\text { Average } \\
\text { Return }\end{array}$ & $\begin{array}{l}\text { Conditional } \\
\text { Covariance }\end{array}$ & $\begin{array}{l}\text { Pricing } \\
\text { Error }\end{array}$ & $\overline{R^{2}}$ & $\begin{array}{c}\text { J Statistic with } \\
\text { common } \\
\text { instruments } \\
\text { (P-value) }\end{array}$ & $\begin{array}{c}\text { J Statistic with } \\
\text { local } \\
\text { instruments } \\
\text { (P-value) }\end{array}$ \\
\hline Australia & 0.0059 & 1.322 & -0.0082 & 0.0858 & $\begin{array}{c}0.073408 \\
(0.0049)\end{array}$ & $\begin{array}{c}0.0601 \\
(0.0158)\end{array}$ \\
\hline Austria & 0.0074 & 1.073 & 0.003448 & 0.0187 & $\begin{array}{c}0.042111 \\
(0.0734)\end{array}$ & $\begin{array}{c}0.0209 \\
(0.3724)\end{array}$ \\
\hline Belgium & 0.0068 & 1.416 & -0.03190 & -0.0050 & $\begin{array}{c}0.048602 \\
(0.0427)\end{array}$ & $\begin{array}{c}0.0556 \\
(0.0234)\end{array}$ \\
\hline Canada & 0.0060 & 1.519 & -0.04153 & 0.0992 & $\begin{array}{c}0.057916 \\
(0.0192)\end{array}$ & $\begin{array}{c}0.0454 \\
(0.0558)\end{array}$ \\
\hline France & 0.0068 & 1.79 & $\begin{array}{c}-7.55 \mathrm{E}-0 \\
5\end{array}$ & -0.0034 & $\begin{array}{c}0.031799 \\
(0.1676)\end{array}$ & $\begin{array}{c}0.0339 \\
(0.1419)\end{array}$ \\
\hline Germany & 0.0070 & 1.968 & -0.00023 & -0.0119 & $\begin{array}{c}0.039426 \\
(0.0914)\end{array}$ & $\begin{array}{c}0.0346 \\
(0.1337)\end{array}$ \\
\hline Hong Kong & 0.0092 & 1.889 & -0.00025 & -0.0140 & $\begin{array}{c}0.049554 \\
(0.0394)\end{array}$ & $\begin{array}{c}0.0487 \\
(0.0422)\end{array}$ \\
\hline Italy & 0.0053 & 1.614 & 0.001289 & -0.0142 & $\begin{array}{c}0.024369 \\
(0.292)\end{array}$ & $\begin{array}{l}0.0341 \\
(0.139)\end{array}$ \\
\hline Japan & -0.0002 & 2.00 & -0.00349 & -0.0101 & $\begin{array}{c}0.049014 \\
(0.0412)\end{array}$ & $\begin{array}{c}0.0489 \\
(0.0414)\end{array}$ \\
\hline $\begin{array}{l}\text { The } \\
\text { Netherlands }\end{array}$ & 0.0065 & 1.642 & 0.000374 & -0.0093 & $\begin{array}{c}0.073870 \\
(0.0047)\end{array}$ & $\begin{array}{c}0.0695 \\
(0.0069)\end{array}$ \\
\hline Spain & 0.0060 & 1.949 & -0.00055 & -0.0144 & $\begin{array}{c}0.019199 \\
(0.420)\end{array}$ & $\begin{array}{c}0.0154 \\
(0.534)\end{array}$ \\
\hline Sweden & 0.0110 & 2.321 & 0.007299 & -0.0109 & $\begin{array}{c}0.042929 \\
(0.0686)\end{array}$ & $\begin{array}{c}0.0299 \\
(0.1939)\end{array}$ \\
\hline Switzerland & 0.0085 & 1.462 & -0.00468 & -0.0102 & $\begin{array}{c}0.051176 \\
(0.0343)\end{array}$ & $\begin{array}{c}0.0424 \\
(0.0716)\end{array}$ \\
\hline $\begin{array}{l}\text { United } \\
\text { Kingdom }\end{array}$ & 0.0048 & 1.558 & -0.01082 & -0.0096 & $\begin{array}{c}0.026026 \\
(0.256)\end{array}$ & $\begin{array}{c}0.0320 \\
(0.1643)\end{array}$ \\
\hline $\begin{array}{c}\text { The United } \\
\text { States }\end{array}$ & 0.0072 & 1.453 & 0.000430 & -0.0125 & $\begin{array}{c}0.044054 \\
(0.0625)\end{array}$ & $\begin{array}{c}0.0448 \\
(0.0587)\end{array}$ \\
\hline G7 & & & & & $\begin{array}{c}0.125419 \\
(0.6026)\end{array}$ & $\begin{array}{c}0.1566 \\
(0.2826)\end{array}$ \\
\hline
\end{tabular}

\section{Conclusion}

International financial integration is a central theme in international finance. Bekaert and Harvey (1995), Carrieri, Errunza and Hogan (2007), showed that the integration degree significantly increased during the Nineties, because of the financial development strategies in emerging markets. A number of studies have examined the financial market integration, several tests were proposed, the integration tests based on the CAPM, the tests using consumption CAPM, the tests based on cointegration technique, etc.

In this paper, we test the conditional version of International CAPM using monthly data of 22 financial markets over the period 1987-2004. The estimates of the model with time-varying moments indicate that the international market is efficient for the group of G7 countries. For emerging markets, the results depend on the choice of the information set. These findings have important implications. The domestic investors will benefit from the market liberalization of G7 through the process of diversification since some of the domestic and foreign risks will offset each other. Moreover, the stock markets will become more stabilized through the process of financial integration.

\section{References}

Akdogan, H. (1996). A suggested approach to country selection in international portfolio diversification. Journal of Portfolio Management, 23, 33-39. http://dx.doi.org/10.3905/jpm.1996.409571

Allen, D., \& MacDonald, G. (1995). The long run gains from international equity diversification: Australian 
evidence from cointegration tests. Applied Financial Economics, 5, 33-42. http://dx.doi.org/10.1080/758527669

Arouri, M. E. H., \& Foulquier, P. (2012). Financial market integration: Theory and empirical results. Economic Modelling, 29, 382-394. http://dx.doi.org/10.1016/j.econmod.2011.11.009

Barari, M. (2004). Measuring equity market integration using market time-varing integration score: The case of Latin America. International Review of Financial Analysis, 13, 649-668. http://dx.doi.org/10.1016/j.irfa.2004.02.019

Bekaert, G., \& Harvey, C. (1995). Time-Varying world market integration. Journal of Finance, 50, 403-444. http://dx.doi.org/10.1111/j.1540-6261.1995.tb04790.x

Boubakri, S., \& Guillaumin, C. (2011). Financial integration and currency risk premium in CEECs: Evidence from the ICAPM. Emerging Markets Review, 12, 460-484. http://dx.doi.org/10.1016/j.ememar.2011.08.001

Carrieri, F., Errunza, V., \& Hogan, K. (2007). Characterizing world market integration through time. Journal of Financial and Quantitative Analysis, 42, 915-940. http://dx.doi.org/10.1017/S0022109000003446

Davies, A. (2006). Testing for international equity market integration using regime switching cointegration techniques. Review of Financial Studies, 15, 305-321.

De Santis, G., \& Gerard, B. (1998). How big is the premium of currency risk? Journal of Financial Economics, 49, 375-412. http://dx.doi.org/10.1016/S0304-405X(98)00029-4

Dumas, B., \& Solnik, B. (1995). The world price of foreign exchange rate risk. Journal of Finance, 50, 445-479. http://dx.doi.org/10.1111/j.1540-6261.1995.tb04791.x

Errunza, V., \& Losq, E. (1985). International asset pricing under mild segmentation: Theory and tests. Journal of Finance, 40, 105-124. http://dx.doi.org/10.1111/j.1540-6261.1985.tb04939.x

Esqueda, O. A., Assefa, T. A., \& Mollick, A. V. (2012). Financial globalization and stock market risk. Journal of International Financial Markets Institutions and Money, 22, 87-102 http://dx.doi.org/10.1016/j.intfin.2011.07.006

Ferson, W. E., \& Harvey, C. R. (1994). Sources of risk and expected returns in global equity markets. Journal of Banking and Finance, 18, 775-803. http://dx.doi.org/10.1016/0378-4266(93)00020-P

Hansen, L. P. (1982). Large sample properties of generalized method of moments estimators. Econometrica, 50, 1029-1054. http://dx.doi.org/10.2307/1912775

Harvey, C. R. (1991). The world price of covariance risk. Journal of Finance, 46, 111-157. http://dx.doi.org/10.1111/j.1540-6261.1991.tb03747.x

Hunter, D. M. (2007). The evolution of stock market integration in the post-liberalization period: A look of Latin America. Journal of International Money and Finance, 25, 795-826. http://dx.doi.org/10.1016/j.jimonfin.2006.06.001

Jorion, P., \& Schwartz, E. (1986). Integration versus segmentation in the Canadian stock market. Journal of Finance, 41, 603-617. http://dx.doi.org/10.1111/j.1540-6261.1986.tb04521.x

Lintner, J. (1965). The valuation of risk assets and the selection of risky investment in stock portfolios and capital budgets. Review of Economics and Statistics, 47, 103-124. http://dx.doi.org/10.2307/1924119

Piesse, J., \& Hearn, B. (2002). Equity market integration versus segmentation in three dominant markets of the Southern African customs union: Cointegration and causality tests. Applied Economics, 34, 1711-1722. http://dx.doi.org/10.1080/00036840110119448

Sharpe, W. (1964). Capital asset prices: A theory of market equilibrium under conditions of risk. Journal of Finance, 19, 425-442.

Solnik, B. (1974). An equilibrium model of the international capital market. Journal of Economic Theory, 8, 111-157. http://dx.doi.org/10.1016/0022-0531(74)90024-6

Stehle, R. (1977). An empirical test of the alternative hypothesis of national and international pricing of risky assets. Journal of Finance, 32, 493-503. http://dx.doi.org/10.1111/j.1540-6261.1977.tb03287.x

Stulz, R. (1981). A model of international asset pricing model. Journal of Financial Economics, 9, 383-406. http://dx.doi.org/10.1016/0304-405X(81)90005-2

Tai, C. S. (2007). Market integration and currency risk in Asian emerging market. Research in International 
Business and Finance, 21, 98-117. http://dx.doi.org/10.1016/j.ribaf.2006.03.001

Wheatley, S. (1988). Some tests of international equity integration. Journal of Financial Economics, 21, 177212. http://dx.doi.org/10.1016/0304-405X(88)90060-8

Yu, I. W., Fung, K. P., \& Tam, C. S. (2010). Assessing financial market integration in Asia-Equity markets. Journal of Banking and Finance, 34, 2874-2885. http://dx.doi.org/10.1016/j.jbankfin.2010.02.010

\section{Notes}

Note 1. In presence of exchange rate risk.

Note 2. The author was based on the literature of Ferson and Harvey (1994), Dumas and Solnik (1995) and De Santis and Gerald (1998).

Note 3. Argentina, Brazil, Chile, Colombia, Mexico and Venezuela.

Note 4. See appendix 1 for the derivation of the equation (3).

Note 5. If we multiply the equation (3) by the conditional variance $E\left[u_{m t}^{2} \mid Z_{t-1}\right\rfloor$, we obtain:

$$
\begin{gathered}
E\left[u_{m t}^{2} \mid Z_{t-1}\right\rfloor \times Z_{t-1} \delta_{j}=E\left[u_{j t} u_{m t}\left|Z_{t-1}\right| \times Z_{t-1} \delta_{m}\right. \\
E\left[u_{m t}^{2} Z_{t-1} \delta_{j} \mid Z_{t-1}\right]=E\left[u_{j t} u_{m t} Z_{t-1} \delta_{m} \mid Z_{t-1}\right]
\end{gathered}
$$

Note 6. Australia, Austria, Belgium, Canada, France, Germany, Hong Kong, Italy, Japan, the Netherlands, Spain, Sweden, Switzerland, United Kingdom, The United States, (15 developed markets), Argentina, Chile, Indonesia, Korea, Malaysia, Mexico and Thailand (7 emerging markets).

Note 7. The change of the US term structure of interest rates is the excess return on a 3 month Treasury bill, the US bond yield spread is measured by the difference in yields between Moody's Baa and Aaa rated bonds.

Note 8 . High $\chi^{2}$ Statistics indicate that the errors are correlated with instrumental variables.

Note 9. If the model is well specified, $\chi^{2}$ and $\overline{R^{2}}$ would be weak.

Note 10. See Appendix 2.

\section{Appendix}

Appendix 1.

We use the equation (1) to evaluate $r_{j t}$ :

$$
E\left[r_{j t} \mid Z_{t-1}\right]=\frac{E\left[r_{m t} \mid Z_{t-1}\right]}{E\left[r_{m t}^{2} \mid Z_{t-1}\right]} E\left[r_{j t}, r_{m t} \mid Z_{t-1}\right]
$$

According to the equation (2): $u_{j t}=r_{j t}-Z_{t-1} \delta_{j}$

And since

$$
\Rightarrow E\left[u_{j t} \mid Z_{t-1}\right]=E\left[r_{j t} \mid Z_{t-1}\right]-Z_{t-1} \delta_{j}
$$

$$
\begin{gathered}
E\left[u_{j t} \mid Z_{t-1}\right]=0 \\
\Rightarrow E\left[r_{j t} \mid Z_{t-1}\right]=Z_{t-1} \delta_{j}
\end{gathered}
$$

In the same way, $u_{m t}$ can be evaluated by using a linear filter:

$$
\begin{gathered}
u_{m t}=r_{m t}-Z_{t-1} \delta_{m} \\
\Rightarrow E\left[u_{m t} \mid Z_{t-1}\right]=E\left[r_{m t} \mid Z_{t-1}\right]-Z_{t-1} \delta_{m}
\end{gathered}
$$


And since

$$
\begin{gathered}
E\left[u_{m t} \mid Z_{t-1}\right]=0 \\
\Rightarrow E\left[r_{m t} \mid Z_{t-1}\right]=Z_{t-1} \delta_{m}
\end{gathered}
$$

Replacing (2.a) and (2.b) in (1.a), we obtain:

$$
Z_{t-1} \delta_{j}=\frac{Z_{t-1} \delta_{m}}{E\left[r_{m t}^{2} \mid Z_{t-1}\right]} E\left[r_{j t}, r_{m t} \mid Z_{t-1}\right]
$$

However

$$
\begin{gathered}
E\left[r_{j t}, r_{m t} \mid Z_{t-1}\right]=E\left[u_{j t}+Z_{t-1} \delta_{j}\left|Z_{t-1}, u_{m t}+Z_{t-1} \delta_{m}\right| Z_{t-1},\right] \\
=E\left[u_{j t}, u_{m t} \mid Z_{t-1}\right]+Z_{t-1} \delta_{m} E\left[u_{j t} \mid Z_{t-1}\right]+Z_{t-1} \delta_{j} E\left[u_{m t} \mid Z_{t-1}\right] \\
=E\left[u_{j t}, u_{m t} \mid Z_{t-1}\right]
\end{gathered}
$$

And

$$
\begin{gathered}
E\left[r_{m t}{ }^{2} \mid Z_{t-1}\right]=E\left[u_{m t}+Z_{t-1} \delta_{m}\left|Z_{t-1}, u_{m t}+Z_{t-1} \delta_{m}\right| Z_{t-1},\right] \\
=E\left[u_{m t}, u_{m t} \mid Z_{t-1}\right]+Z_{t-1} \delta_{m} E\left[u_{m t} \mid Z_{t-1}\right]+Z_{t-1} \delta_{m} E\left[u_{m t} \mid Z_{t-1}\right] \\
=E\left[u_{m t}{ }^{2}\left|Z_{t-1}\right|\right.
\end{gathered}
$$

Thus

$$
Z_{t-1} \delta_{j}=\frac{Z_{t-1} \delta_{m}}{E\left[u_{m t}^{2} \mid Z_{t-1}\right]} E\left[u_{j t} u_{m t} \mid Z_{t-1}\right]
$$

Appendix 2.

The global instrumental variables set: the lagged world excess stock return, a dummy variable for January, the change of the US term structure premia, the US default risk yield spread (4 common instrumental variables).

The local instrumental variables set: the global instruments augmented of the lagged country excess return instead of the lagged world excess stock return (4 local instrumental variables).

Average conditional covariance: The average value of $u_{i} \times u_{m}$ multiplied by 1000 calculated by using country estimate with global instruments.

Average error: The average value of $h_{i}$, calculated by using country estimate with common instruments, divided by the conditional variance of the world market return.

$R^{2}$ : The adjusted coefficient of determination, which results from the regression of the model errors $\left(h_{i}\right)$ on global instrumental variables.

J Statistic: represents the minimized value of the function criterion of GMM. This statistic converges towards $\chi^{2}$ with degrees of freedom equal to the number of moment conditions minus the number of parameters. Since the model presents $l$ information variables, there will be thus $[l \times(2 n+1)]$ moment conditions, $[l \times(n+1)]$ parameters to be estimated and consequently $l \times n$ overidentifying restrictions.

For single countries with common and local instruments, there are 12 moment conditions, 8 parameters, and thus 4 overidentifying conditions. For the group of G7 countries, there are 60 moment conditions, 32 parameters and 28 overidentifying conditions for the estimate with common and local instruments.

P-value: is the probability that a $\chi^{2}$ statistic exceeds the sample value of the statistic. 


\section{Copyrights}

Copyright for this article is retained by the author(s), with first publication rights granted to the journal.

This is an open-access article distributed under the terms and conditions of the Creative Commons Attribution license (http://creativecommons.org/licenses/by/3.0/). 